\title{
Capitulum characters in a seed heteromorphic plant, Crepis sancta (Asteraceae): variance partitioning and inference for the evolution of dispersal rate
}

\author{
ERIC IMBERT* \\ C.E.F.E./C.N.R.S., F-34093 Montpellier, France
}

\begin{abstract}
In Crepis sancta (Asteraceae), achenes produced in the periphery of the flower head have reduced dispersal ability and are larger than achenes produced in the centre of the head, which disperse farther. The proportion of central achenes produced by a single individual represents the potential dispersal rate of its progeny. Seed variation in dispersal ability may be important where there is spatio-temporal variability of habitats, but its evolutionary significance mainly depends on the heritability of the relative proportions of each achene morph. However, the number of peripheral achenes in a capitulum, and that of involucral bracts are suggested to depend on the number of parastichies, a canalized character. From a diallel cross design, phenotypic variance for several capitulum traits was partitioned among six variance components, including the additive variance. The phenotypic values of some head traits reflected the expected frequency due to ontogeny, in particular the number of involucral bracts. Yet, this character also had a significant heritability, suggesting that variation around the mode of the distribution was not only due to developmental noise. The additive variance for number of peripheral and central achenes was not significantly different from zero. In contrast, their respective proportion had a narrow sense heritability greater than 0.20 . The present results suggest that the percentage of central achenes per individual, and thus the potential dispersal rate in Crepis sancta, is under quantitative genetic control, and could undergo microevolutionary changes in natural populations.
\end{abstract}

Keywords: capitulum ontogeny, dispersal rate, seed heteromorphism.

\section{Introduction}

Seed heteromorphism, i.e. the production of different seed morphs by a single individual, is recognized as a way in which plants may cope with spatio-temporal variability of habitats (Venable, 1985; Venable et al., 1998). This relies on ecological differentiation among seed morphs for dormancy, dispersal or competitive ability (see references in Ruiz de Clavijo \& Jimenez, 1998; Imbert, 1999). For instance, in most seed heteromorphic Asteraceae species, achenes (i.e. single seeded fruits) produced by peripheral florets, hereafter peripheral achenes, lack dispersal structures (e.g. pappus, trichomes, etc.), and thus have reduced dispersal capacity, whereas central achenes disperse farther because they

*Correspondence and present address: I.S.E.M., Génétique et Environnement, Université Montpellier II-CC 065, F-34095 Montpellier cedex 5 France. E-mail: imbert@isem.univ-montp2.fr possess dispersal structures (Imbert, 1999). Therefore, the percentage of central achenes produced by a single individual represents the potential dispersal rate among its progeny.

Obviously, the relative proportion of each seed morph produced by a single individual is a key feature (Venable, 1985). Yet, few studies have focused on genetic variation in seed morph proportions (see references in Imbert et al. (1999) for Asteraceae species; see also Cheplick \& Quinn (1988) for seed heteromorphism in relation to amphicarpy). More scarce are studies of the heritability of seed morph proportions, although estimation of heritability is needed to infer the origin of variation within and among populations (Venable et al., 1998). For Asteraceae species, Venable \& Burquez (1989) proposed values of broad-sense heritability greater than 0.25 for Heterosperma pinnatum, based on estimation of within- and among-family variances. However, the results obtained for this species cannot 
hold for all heteromorphic Asteraceae, since achene morphs in $H$. pinnatum have an uncommon pattern of arrangement within the seed head.

Indeed, in $H$. pinnatum, there is no relation between position within the head and achene morphology (Venable \& Burquez, 1989), whereas in most seed heteromorphic Asteraceae, there is a close correspondence between morphology of the achene and its position within the capitulum. Thus, peripheral type achenes are only produced by peripheral florets (Pomplitz, 1956; Bachmann, 1983). Consequently, the study of achene morph proportions must take into account other capitulum traits, in particular those affected by developmental constraints. The main developmental constraint in the capitulum is the number of phyllotactic spirals, i.e. parastichies, which is a canalized character. For instance, in Lactuceae species, the number of parastichies is suggested to be canalized on 13 (Battjes et al., 1992, 1993). As the number of parastichies controls for number of involucral bracts, and number of peripheral florets (Bachmann, 1983), such characters are expected to show no genetic variance. However, the number of peripheral achenes may vary widely due to pollination failure and abortion (Imbert et al., 1999). The number of central florets, and potentially central achenes, is determined by the length of each parastichy, i.e. the number of florets produced by each parastichy. Consequently, the number of central achenes is strongly correlated with the total fecundity of the head (Zentgraf et al., 1985; Imbert et al., 1999).

Here, I report an analysis of variance components for capitulum characters in the seed heteromorphic Asteraceae Crepis sancta. In this species, peripheral achenes are light-coloured, have no pappus and are larger than central achenes, which have a pappus. Achenes of intermediate morphology are also found within seed heads of some individuals. It has been shown (Imbert et al., 1997; Imbert, 1999) that plants from peripheral achenes have a greater competitive ability than those from central achenes, and peripheral achenes fall close to the mother plant whereas central achenes have a great wind-dispersal ability. In the present study, a diallel cross design is used to partition the variance of several traits related to the capitulum, in particular proportion of central achenes.

\section{Materials and methods}

\section{The species}

Crepis sancta is an annual herb commonly found in the Mediterranean area of France. Germination occurs in autumn, and individuals overwinter at a rosette stage. Flowering occurs early in spring (February-March), and lasts two to three weeks. The species is allogamous and insect-pollinated, but a few self-compatible genotypes can be found in natural populations (Cheptou et al., 2000). Flowers are arranged according to the typical capitulum of Asteraceae. Involucral bracts are divided into two morphologically distinct groups: the outer ones, which are short and oval, and the inner ones, which are long and lanceolate. Previous studies on C. sancta (Imbert et al., 1999) and other Lactuceae species (Battjes et al., 1993; Vlot \& Bachmann, 1993) suggested that the number of inner bracts is canalized on 13 , as is the number of parastichies. All the florets within each capitulum are ligulate, yellow and hermaphrodite, and there are no morphological differences between peripheral and central florets.

\section{Crossing design}

In spring 1994, one mature seed head was collected from each of a hundred plants in a natural population at Saint-Mathieu de Tréviers (near Montpellier, South of France). In the area, Crepis sancta is abundant in cultivated fields, old-fields and road verges. Therefore, the sampled population was not recently founded or isolated. Achenes within one seed head form a family. Among the 100 families sampled, 10 were selected to increase the distance among sampled plants, and thus to decrease the likelihood of sampling closely related individuals. Ten seeds from each family were germinated in Petri dishes (one dish per family) with distilled water. Germination occurred in a greenhouse (photoperiod $12: 12$, temperature $20^{\circ} \mathrm{C}: 10^{\circ} \mathrm{C}$ ). Seedlings were individually transplanted to $50 \mathrm{~cm}^{3}$ pots containing $1: 1$ sterile soil:compost. One month later, plants were individually transplanted to 1 litre pots containing the same soil mixture. One plant per family was randomly chosen. These 10 individuals representing generation 0 were used in a diallel cross design (Griffing, 1956), a protocol in which each plant is used both as pollen donor and pollen recipient. Self-compatibility was tested for each of the 10 individuals, but self-pollination always failed to produce seeds; thus the design was a partial diallel. Plants were kept in an insect-proof greenhouse, and hand pollinations were made between $11.00 \mathrm{AM}$ and $12.00 \mathrm{AM}$. Prior to pollination, a flower head of the recipient was brushed to remove pollen, then pollen from the donor was brushed onto the head. Among the 90 possible crossings, only 63 produced viable seeds. Pollination failure was possibly caused by sensitivity of pollen to desiccation, a common feature in Asteraceae. However, the effect of the incompatibility system cannot be excluded. Mature seeds were stored in laboratory conditions until autumn 1995 when progeny were raised using the same protocol (germination, seedling transplanting, growth) as above. 
For each of the 63 families, 10 seeds were germinated and five seedlings were randomly selected, totalling 315 individuals, but because of mortality, only 291 individuals have been used. During reproduction, plants were placed outdoors in the experimental garden of the Centre d'Ecologie Fonctionnelle et Evolutive (Montpellier), where several thousands of plants were cultivated. Therefore, there was no pollen limitation, and the likelihood of crosses between related individuals was low. During reproduction, three flower heads were sampled for counts of the number of outer and inner bracts and the total number of florets per head. Three mature seed heads were also sampled to count the number of peripheral, intermediate and central achenes (Table 1). Those characters were used to compute other characters of interest (Table 1). In particular, the ratio (number of florets/number of inner bracts, FLORET/ INNER, Table 1) provides information about the length of the parastichies.

\section{Data analysis}

The distribution of each character was investigated by computing its coefficient of variation (standard deviation $\times 100 /$ mean), its skewness $\left(g_{1}\right.$, a negative value indicates skewness to the left), and its kurtosis $\left(\mathrm{g}_{2}\right.$, a leptokurtic distribution has a positive value). Both skewness and kurtosis were tested against zero with a $t$-test (Sokal \& Rohlf, 1995).

Data were analysed according to the 'bio' model of Cockerham \& Weir (1977), and phenotypic variance
$\left(\mathrm{V}_{\mathrm{p}}\right)$ was partitioned into the following six components: $\mathrm{V}_{\mathrm{a}}$ and $\mathrm{V}_{\mathrm{d}}$, additive and dominance variance, respectively, due to nuclear genes; $V_{\text {mat }}$, maternal variance caused by cytoplasmic genes, and maternal environmental effects; $V_{\text {pat }}$, paternal variance; $V_{\mathrm{k}}$, variance resulting from the interaction between nuclear genes from one parent with extranuclear genes from the second parent; and $\mathrm{V}_{\mathrm{e}}$, environmental variance (Shaw \& Platenkamp, 1993). Variance components were computed with the NF6 program of the QUERCus package (Shaw \& Shaw, 1994). Since this program does not allow the differentiation of repeated measures on a single individual from repeated full-sibs within a single family, data analyses were performed on the mean value for each trait per individual. Because of an unbalanced design, i.e. the number of individuals varied among full-sib families, variance components were estimated using the REML method (Shaw, 1987).

Variances components were first estimated with an unconstrained analysis, i.e. variances were allowed to be negative. Thus, components that were estimated as negative were constrained to 0 . This model was considered as the full model, characterized with a loglikelihood value noted $\mathrm{L}_{\max }$. Thus, for each component that was not negative in the full model, a new model was tested constraining the component in question to 0 . This model was characterized with a log-likelihood value noted $\mathrm{L}_{0}$. To test whether components were significantly different from zero, a likelihood ratio test was used $\left[\mathrm{L}=-2\left(\mathrm{~L}_{0}-\mathrm{L}_{\max }\right)\right]$, and compared with a $\chi^{2}$ with 1 degree of freedom. Finally, genetic correlations were

Table 1 List of the characters measured on flowering heads and mature seed heads of Crepis sancta and their abbreviation, mean value, standard deviation, coefficient of variation and ranges

\begin{tabular}{|c|c|c|c|c|c|}
\hline Characters & Abbreviation & Mean & SD & $\mathrm{CV}$ & Range \\
\hline Number of outer bracts & OUTER & 8.9 & 1.7 & 18.6 & $5-16$ \\
\hline Number of inner bracts & INNER & 13.2 & 1.0 & 7.7 & $8-19$ \\
\hline $\begin{array}{l}\text { Number of bracts } \\
\text { (OUTER + INNER) }\end{array}$ & BRACT & 22.1 & 2.2 & 9.8 & $14-33$ \\
\hline Total number of florets per head & FLORET & 79.8 & 13.7 & 17.1 & $21-120$ \\
\hline $\begin{array}{l}\text { Length of parastichies } \\
\text { (FLORET/INNER) }\end{array}$ & LENGTH & 6.1 & 1.0 & 16.8 & $1.2-9.1$ \\
\hline Number of peripheral achenes & PA & 9.6 & 2.2 & 23.4 & $3-16$ \\
\hline Number of intermediate achenes & IA & 2.5 & 2.7 & 106.1 & $0-14$ \\
\hline Number of central achenes & $\mathrm{CA}$ & 60.8 & 11.9 & 19.5 & 25-94 \\
\hline $\begin{array}{l}\text { Total number of achenes per head } \\
\text { (PA + IA + CA) }\end{array}$ & ACHE & 72.9 & 12.4 & 17.0 & $36-108$ \\
\hline $\begin{array}{l}\text { Percentage of peripheral achenes } \\
\text { (PA/ACHE) }\end{array}$ & PPA & 0.13 & 0.03 & 24.5 & $0.04-0.25$ \\
\hline $\begin{array}{l}\text { Percentage of intermediate achenes } \\
\text { (IA/ACHE) }\end{array}$ & PIA & 0.03 & 0.03 & 105.2 & $0-0.19$ \\
\hline $\begin{array}{l}\text { Percentage of central achenes } \\
\text { (CA/ACHE) }\end{array}$ & PCA & 0.83 & 0.05 & 6.1 & $0.62-0.95$ \\
\hline
\end{tabular}


estimated as Covariance( Trait $_{1}$, Trait $\left._{2}\right) /$ square root $\left[\mathrm{V}_{\mathrm{a}}\right.$ $\left(\right.$ Trait $\left._{1}\right)\left(\mathrm{V}_{\mathrm{a}}\left(\right.\right.$ Trait $\left.\left._{2}\right)\right]$, and tested against zero in the same way as for variance components (Lynch \& Walsh, 1998).

\section{Results}

\section{Distribution of characters} and phenotypic correlations

A total of 866 flowering heads were collected, of which 264 had 8 outer bracts (kurtosis $\mathrm{g}_{2}=1.00, t=6.02$,
$P<0.001$ for $\mathrm{H}_{0}: \mathrm{g}_{2}=0$, Fig. 1a). For INNER (number of inner bracts), the value of kurtosis $\left(\mathrm{g}_{2}=6.30\right.$, test against zero: $\left.t=37.84, P<0.001\right)$ indicated a high leptokurtic distribution, and 602 heads (69.5\%) had 13 inner bracts (Fig. 1b). Furthermore, INNER had a very low coefficient of variation $(7.7 \%$, Table 1). The variation observed in OUTER (number of outer bracts) was evident for the total number of bracts (Fig. 1c), however, there was a pronounced preference for 21 bracts per head $\left(\mathrm{g}_{2}=2.49\right.$, Fig. 1c). Phenotypic correlations among these traits were all positive and
A- OUTER

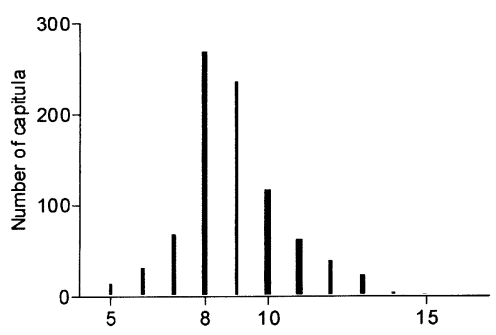

C-BRACT

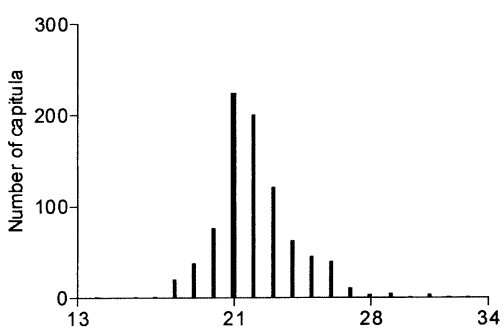

E-PA

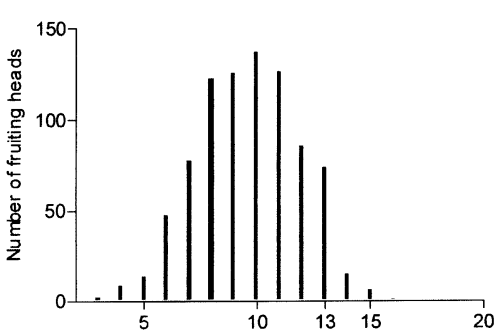

G CA

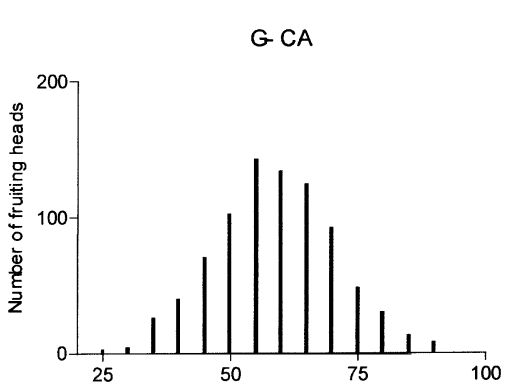

B- INNER

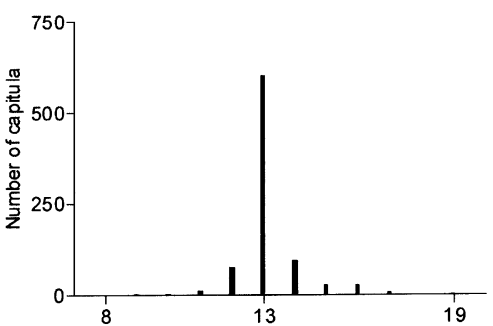

D- FLORET

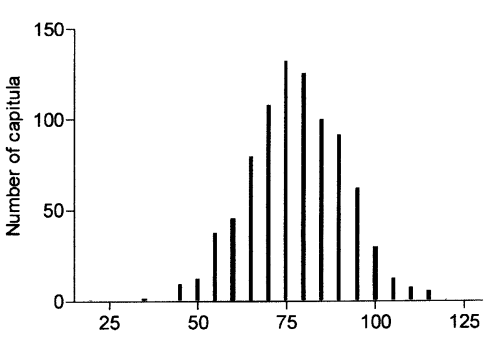

F- IA

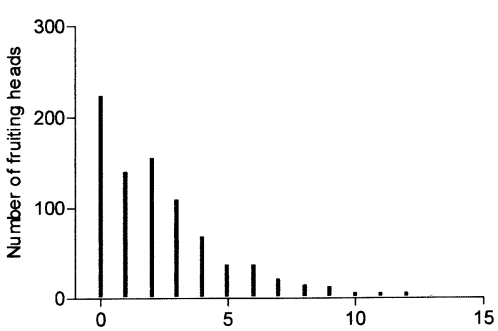

Fig. 1 Frequency distribution of characters related to flowering head (OUTER, INNER, BRACT, FLORET) and to seed heads (PA, IA and CA) in Crepis sancta. For abbreviations, see Table 1.

(C) The Genetics Society of Great Britain, Heredity, 86, 78-86. 
significant (Table 2). The total number of florets per head (FLORET) did not show such bias in its distribution, and both its skewness $\left(\mathrm{g}_{1}=-0.06\right)$ and its kurtosis $\left(\mathrm{g}_{2}=0.19\right)$ were not significantly different from zero $(t=0.72$, and $t=1.14$, respectively, and $P>0.25$ for both values, Fig. 1d). The average number of florets per parastichy (LENGTH) was 6.1 (Table 1), and $67.2 \%$ of the capitula had a value ranging between 5 and 7. Phenotypic correlation between FLORET and LENGTH was higher than the correlation between FLORET and the number of bracts (Table 2).

Of the 846 collected fruiting heads 824 had less than 14 peripheral achenes (Fig. 1e), and the mean number of peripheral achenes per head (9.6, Table 1) was significantly different from $13(t=43.53, P<0.001)$, the usual number of parastichies in Lactuceae species (see Introduction). Furthermore, the phenotypic correlation between PA (number of peripheral achenes) and INNER was not significantly different from zero (Table 2). The mode of the distribution of IA (number of intermediate achenes) was zero (Fig. 1f), and more than $25 \%$ of the fruiting heads ( 224 out of 846 ) had no intermediate achene. IA had a distribution highly skewed to the right $\left(\mathrm{g}_{1}=1.49, t=17.98, P<0.001\right)$ with a coefficient of variation greater than $100 \%$ (Table 1). Conversely, the distribution of CA (number of central achenes) did not show any extreme pattern, and values of skewness and kurtosis were not significantly different from zero (Fig. 1g). On average, central achenes represented more than $80 \%$ of the total fecundity of seed heads (Table 1), and for 588 fruiting heads, the percentage of central achenes (PCA) was greater than $75 \%$. Such a pattern led to a high correlation between CA and the total number of achenes per head (ACHE, Table 2). Furthermore, the regression coefficient $(\mathrm{b}=0.999 \mathrm{SD}=0.010, n=846)$ did not differ significantly from unity $\left(t=-0.04, P>0.95\right.$ for $\mathrm{H}_{0}$ : $\mathrm{b}=1$ ). Conversely, PA was only slightly correlated to ACHE (Table 2), and the correlation between IA and ACHE was not significantly different from zero (Table 2). These patterns lead to negative correlations between PPA (percentage of peripheral achenes) and CA, and PPA and ACHE (Table 2). Finally, IA was highly negatively correlated with PCA (Table 2), with individuals that did not make intermediate achenes producing more central achenes than those which produced intermediate achenes $(87.6 \%$ vs. $82.6 \%)$, without change in total fecundity (71.3 vs. 72.9$)$.

\section{Variance partitioning and genetic correlations}

Maternal components were significant and accounted for at least $6 \%$ of the total variance for all the characters related to flowering head (OUTER, INNER, BRACT,

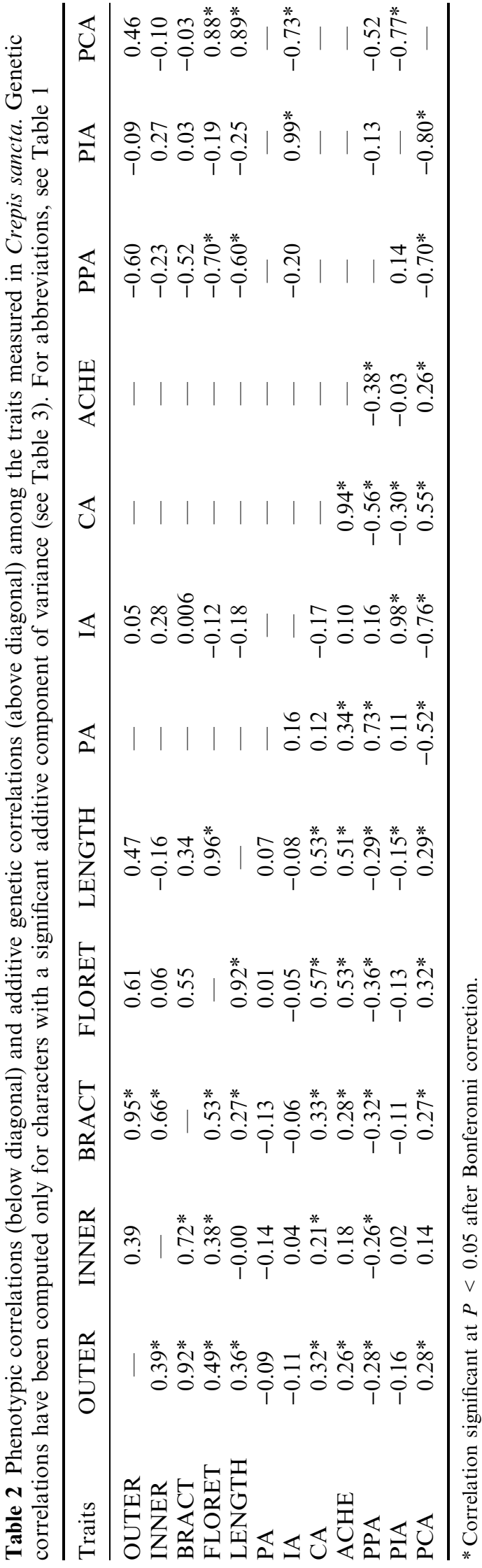

(c) The Genetics Society of Great Britain, Heredity, 86, 78-86. 
Table 3 Estimations of variance components for each character (first row), and percentage of variance (second row) in Crepis sancta. Variance components that were estimated as negative were constrained to 0 . Significance of components was obtained by comparing the log-likelihood value for the null model with the value obtained for a model constraining the component in question to 0 . For more details, see data analyses section. Abbreviations are given in Table 1

\begin{tabular}{|c|c|c|c|c|c|c|}
\hline & $\mathrm{V}_{\mathrm{a}}$ & $\mathrm{V}_{\mathrm{d}}$ & $\mathrm{V}_{\text {mat }}$ & $\mathrm{V}_{\text {pat }}$ & $\mathrm{V}_{\mathrm{k}}$ & $\mathrm{V}_{\mathrm{e}}$ \\
\hline OUTER & $\begin{array}{l}0.48 * * * \\
32.2\end{array}$ & & $\begin{array}{l}0.15^{* * * *} \\
10.0\end{array}$ & & & $\begin{array}{l}0.86^{*} \\
57.6\end{array}$ \\
\hline INNER & $\begin{array}{l}0.08 * \\
16.2\end{array}$ & & $\begin{array}{l}0.07^{* * * *} \\
15.7\end{array}$ & & & $\begin{array}{l}0.34^{* *} \\
68.1\end{array}$ \\
\hline BRACT & $\begin{array}{l}0.74 * * \\
27.7\end{array}$ & $\begin{array}{l}0.007 \mathrm{NS} \\
0.29\end{array}$ & $\begin{array}{l}0.34 * * * \\
12.9\end{array}$ & & & $\begin{array}{l}1.57 \mathrm{NS} \\
59.0\end{array}$ \\
\hline FLORET & $\begin{array}{l}30.40 * \\
24.4\end{array}$ & $\begin{array}{l}5.14 \mathrm{NS} \\
4.1\end{array}$ & $\begin{array}{l}8.32 * \\
6.7\end{array}$ & & & $\begin{array}{l}80.88 * \\
64.8\end{array}$ \\
\hline LENGTH & $\begin{array}{l}0.19 * * * \\
31.4\end{array}$ & $\begin{array}{l}0.04 \mathrm{NS} \\
5.9\end{array}$ & $\begin{array}{l}0.009 \mathrm{NS} \\
1.5\end{array}$ & & & $\begin{array}{l}0.37 * \\
61.2\end{array}$ \\
\hline PA & $\begin{array}{l}0.32 \mathrm{NS} \\
9.4\end{array}$ & & $\begin{array}{l}0.19 \mathrm{NS} \\
5.4\end{array}$ & $\begin{array}{l}0.11 \mathrm{NS} \\
3.3\end{array}$ & & $\begin{array}{l}2.85^{* *} \\
81.8\end{array}$ \\
\hline IA & $\begin{array}{l}4.36^{* * * *} \\
75.3\end{array}$ & $\begin{array}{l}0.48 \mathrm{NS} \\
8.3\end{array}$ & & & $\begin{array}{l}0.13 \mathrm{NS} \\
2.3\end{array}$ & $\begin{array}{l}0.81 \mathrm{NS} \\
13.9\end{array}$ \\
\hline $\mathrm{CA}$ & $\begin{array}{l}17.89 \mathrm{NS} \\
9.3\end{array}$ & $\begin{array}{l}10.24 \mathrm{NS} \\
5.3\end{array}$ & $\begin{array}{l}10.22 \mathrm{NS} \\
5.3\end{array}$ & & & $\begin{array}{l}154.59 * * * \\
80.1\end{array}$ \\
\hline ACHE & $\begin{array}{l}17.25 \mathrm{NS} \\
7.5\end{array}$ & $\begin{array}{l}4.56 \mathrm{NS} \\
1.9\end{array}$ & $\begin{array}{l}13.40 \mathrm{NS} \\
5.8\end{array}$ & & $\begin{array}{l}1.37 \mathrm{NS} \\
0.6\end{array}$ & $\begin{array}{l}192.28 * * * \\
84.0\end{array}$ \\
\hline PPA & $\begin{array}{l}12.44^{*} \\
24.9\end{array}$ & $\begin{array}{l}6.13 \mathrm{NS} \\
10.7\end{array}$ & & & $\begin{array}{l}1.07 \mathrm{NS} \\
1.9\end{array}$ & $\begin{array}{l}25.59 * * \\
62.4\end{array}$ \\
\hline PIA & $\begin{array}{l}12.16^{* * * *} \\
73.7\end{array}$ & $\begin{array}{l}2.13 \mathrm{NS} \\
12.9\end{array}$ & & & & $\begin{array}{l}2.19 \mathrm{NS} \\
13.3\end{array}$ \\
\hline PCA & $\begin{array}{l}18.84 * * \\
26.6\end{array}$ & $\begin{array}{l}11.02 \mathrm{NS} \\
14.1\end{array}$ & & & & $\begin{array}{l}41.87 * \\
59.2\end{array}$ \\
\hline
\end{tabular}

NS, not significant, $P>0.05 ; * P<0.05 ; * * P<0.01 ; * * P<0.001$.
FLORET, Table 3), except LENGTH. Estimations of additive components showed values ranging from $16.2 \%$ for INNER to $32.2 \%$ for OUTER, and every value was significantly greater than zero (Table 3 ). Genetic correlations among these traits showed a pattern similar to that obtained with phenotypic correlations (Table 2).

For the number of peripheral achenes, that of central achenes, and the total number of achenes per head (PA, $\mathrm{CA}$, and ACHE, respectively), all components but $\mathrm{V}_{\mathrm{e}}$, were lower than $10 \%$ and not significantly greater than zero (Table 3). In particular, the estimation of the additive variance was lower than $10 \%$, and was never significantly different from zero $(P=0.48$ for PA, 0.22 for CA and 0.28 for ACHE, Table 3). Consequently, no genetic covariance was estimated for these traits (Table 2). Conversely, the additive variance for IA accounted for $75.3 \%$ of the total variance (Table 3), and was the only significant component for this trait, suggesting a very high heritability for number of intermediate achenes. Actually, 31 progeny out of the 291 did not produce intermediate achenes, and these genotypes were closely related, since 18 originated from a single parent, either as father or as mother. PIA showed the same pattern as IA (Table 3). Excluding these individuals from the analysis, additive variance accounted for $74.0 \%$ of the total phenotypic variance of IA. Correlations between IA (or PIA) and traits related to the flowering heads were never significant (Table 2). Finally, additive variance components were significant for both percentage of peripheral achenes and that of central achenes (Table 3), and narrow-sense heritability was approximately 0.25 for both traits. For PPA, additive genetic correlations were significant only with FLORET and LENGTH; these values were negative and greater than the phenotypic correlations (Table 2). For the genetic correlations between PCA and FLORET and LENGTH, a similar pattern was observed (Table 3), except that values were positive.

\section{Discussion}

Although plants in the first generation were grown in controlled conditions, estimates of the maternal component of variance were significantly greater than zero 
for traits related to flowering heads, including number of bracts and total number of florets per head. Nongenetic maternal effects are usually expected in early seedling traits, such as seed mass and germination time, rather than at the flowering stage (Byers et al., 1997; Thiede, 1998). Previous studies conducted on Crepis sancta have shown that such early generation nongenetic effects disappear during growth in controlled conditions (Imbert et al., 1999). However, the maternal component also includes effects of cytoplasmic genes. Except for sex determination in gynodioecious species, cytoplasmic genes are not usually known to affect morphological traits. In Papaver somniferum, reciprocal crosses suggested that resistance to mildew is under the control of cytoplasmic inheritance, and depends on leaf morphology (Dhawan et al., 1998). Thus, the cytoplasmic genome could affect leaf morphology. Ogihara et al. (1997) have reported that mitochondrial genes influence flower morphogenesis in Aegilops crassa, while a similar effect was obtained in Nicotiana for petal and stamen development (Bonnett et al., 1991; Kofer et al., 1991). Consequently, it is possible that flowering head morphology in Crepis sancta is also affected by cytoplasmic genes, but this clearly requires testing.

In plant species, canalized characters usually have a distribution centred on a number belonging to the Fibonacci sequence $(0,1,1,2,3,5,8,13,21, \ldots$ where $\mathrm{u}_{n+2}=\mathrm{u}_{n+1}+\mathrm{u}_{n}$, and $\mathrm{u}_{0}=0$ and $\mathrm{u}_{1}=1$; Bachmann \& Chambers, 1990; Briggs \& Walters, 1997). Such canalization on 13 is obvious for the number of inner bracts, consistent with previous results on Crepis sancta (Imbert et al., 1999) and other Lactuceae species (Battjes et al., 1992, 1993; Vlot \& Bachmann, 1993). Numerical canalization is less obvious for the number of outer bracts (see also Battjes et al., 1993). Note that the mode of the distribution for OUTER was 8, and 13 for INNER, two consecutive numbers in the Fibonacci sequence. Phenotypic variation in canalized characters is suggested to result from developmental noise, arising from accidents of developments. However, the present study shows that the numbers of outer and inner bracts have significant additive variance. Therefore, the variability around 8 for OUTER and 13 for INNER - and 21 for the total number of bracts - has partly a genetic basis in Crepis sancta. Genetic variation in number of involucral bracts has also been reported in Microseris douglasii (Vlot \& Bachmann, 1993) and in M. pygmaea (Battjes et al., 1993).

Some correlations presented here are trivial results because of nonindependence of the characters being compared (e.g. number of peripheral achenes, that of central achenes, and total number of achenes per head), but they illustrate the effect of ontogeny on capitulum characters (Zentgraf et al., 1985; Imbert et al., 1999).
For instance, the number of peripheral achenes per head is suggested to be bounded to 13 (see introduction), which was observed for $97.3 \%$ of the sampling heads, thus its correlation with the total fecundity of the seed head is low, but significant. In contrast, the number of central achenes is highly correlated with the total fecundity of the seed head, because central achenes are preponderant within a seed head. These correlations have some consequences on the pattern of variation in the number of each achene morph, and their respective proportions (Imbert et al., 1999). As Crepis sancta is an annual species, the total fecundity of one seed head, and the number of seed heads, is mainly determined by biomass accumulation during the vegetative period, and thus by environmental conditions. Furthermore, pollination failure and abortion also generate environmental variance. Therefore its heritability, as that of associated characters (number of peripheral and central achenes), is expected to be low or null, since environmental variance represents the main component. In contrast, the number of intermediate achenes per seed head was not significantly correlated with the total fecundity. Therefore, this character is not submitted to the same constraints as the number of peripheral and central achenes. It thus showed a very high value of heritability, and individuals that did not produce this kind of achenes were closely related. These differences among the three achene morphs suggest that intermediate achenes would be relevant to an investigation of the genetic basis of differentiation between achenes, i.e. the ontogeny of achene heteromorphism.

The most interesting point of the present study is that the heritabilities of peripheral and central achenes were not significant, whereas the narrow-sense heritabilities of their respective percentages were high. Therefore, it appears that the percentage of central achenes, in particular in Crepis sancta, is not only the result of developmental constraints, as suggested by previous studies (Bachmann, 1983; Imbert et al., 1999), or a plastic trait (Imbert \& Ronce, in press), but it is also a trait genetically determined. Equivalent results have been obtained for amphicarpic species (Cheplick \& Quinn, 1988), and for other Asteraceae species (Venable \& Burquez, 1989; Bachmann \& Chambers, 1990). As central achenes in Crepis sancta have a high dispersal ability compared to that of peripheral achenes (Imbert, 1999), the percentage of central achenes represents the potential dispersal rate. The fact that the character exhibits a high narrow-sense heritability suggests that either the potential dispersal rate is a neutral character with a transitory polymorphism, or is under some sort of balancing selection (Cohen \& Levin, 1991). Many ecological investigations have pointed out the importance of seed dispersal for plant species (see references in 
Imbert, 1999; and in Ouborg et al., 1999). Furthermore, in C. sancta, the preponderance of the dispersed achene morph within seed heads suggests dispersal is an important feature; an observation to be related to the colonization ability of the species (Imbert et al., 1999). Finally, many theoretical studies have focused on the evolution of dispersal rate, in particular in a metapopulation context (Olivieri et al., 1995), and confirmed the importance of seed dispersal for sessile organisms such as plants. In particular, Olivieri et al. (1995) showed that dispersal rate experiences antagonistic selective forces at the withinpopulation level (selection favours a low dispersal rate) and at the metapopulation level (selection favours a high dispersal rate). Furthermore, in most seed heteromorphic species, seed morphs also differ for several ecological characters. For instance, in the annual Heterosperma pinnatum, morphs differ for dispersal and dormancy, thus seed morph proportions change with vegetation composition and amount of precipitation (Venable et al., 1998). In $C$. sancta, seedlings from peripheral achenes have a greater initial mass than the ones from central achenes, conferring an advantage in competitive conditions (Imbert et al., 1997). These differences between seed morphs might also contribute to the maintenance of genetic variation for seed morph proportions.

The presence of genetic variation in seed morph proportions and potential dispersal rate allows these traits to be locally adapted. Previous observations in Crepis sancta (Imbert, unpublished data) showed that the proportion of central achenes decreases with age of populations along a successional process. Similar patterns have been observed in two seed heteromorphic Carduus species (Olivieri \& Gouyon, 1985), consistent with theoretical predictions (Olivieri et al., 1995). Peroni (1994) and Cody et al. (1996) have also focused on among-population variation in characters related to dispersal ability (samara morphology in Acer rubrum, and achene morphology in several Asteraceae species, respectively), and concluded that potential dispersion varied in a consistent way with theoretical prediction. All these observations suggest that, in plant species, potential of dispersal cannot be only viewed as a plastic character, mainly maternally induced (Donohue, 1999). In particular, the present study demonstrated that in Crepis sancta dispersal rate has a genetic basis, thus the species appears to be an interesting species to investigate some theoretical predictions about the evolution of dispersal rate, in particular in regard to metapopulation dynamics, and habitat fragmentation.

\section{Acknowledgements}

I am particularly grateful to Isabelle Olivieri, Ophélie Ronce and two anonymous reviewers for their helpful

(C) The Genetics Society of Great Britain, Heredity, 86, 78-86. comments, Renaud Vitalis for his help about the Quercus package, and Christian Collin for help on cultivation. This is publication number ISEM 2000-106 of the Institut des Sciences de l'Evolution, Université Montpellier 2. This work was partly supported by E. C. TMR "Plant dispersal".

\section{References}

BACHMANN, K. 1983. Evolutionary genetics and the genetic control of morphogenesis in flowering plants. Evol. Biol., 16, 157-208.

BACHMANN, K. AND CHAMBERS, K. L. 1990. Heritable variation for heterocarpy in Microseris bigelovii (Asteraceae-Lactuceae). Beitr. Biol. Pfl., 65, 123-146.

BATTJES, J., BACHMANN, K. AND BOUMAN, F. 1992. Early development of capitula in Microseris pygmaea D. Don strains C96 and A92 (Asteraceae-Lactuceae). Bot. Jahrb. Syst., 113, 461-475.

BATtJeS, J., VISCHER, N. O. E. AND BACHMANN, K. 1993. Meristem geometry and heritable variation in number of florets and involucral bracts in Microseris pygmaea (Asteraceae, Lactuceae). Acta Bot. Neerland, 42, 255-268.

BONNETT, H. T., KOFER, W., HAKANSSON, G. AND GLIMELIUS, K. 1991. Mitochondrial involvement in petal and stamen development studied by sexual and somatic hybridization of Nicotiana species. Plant Sci., 80, 119-130.

BRIGgS, D. AND WAlters, S. M. 1997. Plant Variation and Evolution. Cambridge University Press, Cambridge.

BYERS, D. L., PLATENKAMP, A. J. AND SHAW, R. G. 1997. Variation in seed characters in Nemophila menziesii: evidence for genetic basis for maternal effect. Evolution, 51, 1445-1456.

CHEPLICK, G. P. AND QUINN, J. A. 1988. Quantitative variation of life history traits in amphicarpic peanutgrass (Amphicarpum purshii) and its evolutionary significance. Am. J. Bot., 75, 123-131.

CHEPTOU, P. O., IMBERT, E., LEPART, J. AND ESCARRE, J. 2000. Effects of competition on lifetime estimates of inbreeding depression in the outcrossing plant Crepis sancta (Asteraceae). J. Evol. Biol., 13, 522-531.

COCKERHAM, C. C. AND WEIR, B. S. 1977. Quadratic analysis of reciprocal crosses. Biometrics, 33, 187-203.

CODY, M., L. AND OVERTON, J. McC. 1996. Short-term evolution of reduced dispersal in island plant populations. J. Ecol., 84, 53-61.

COHEN, D. AND LEVIN, S. A. 1991. Dispersal in patchy environments: the effects of temporal and spatial structure. Theor. Pop. Biol., 39, 63-99.

DHAWAN, O. P., SHARMA, J. R., DWIVEDI, S. AND LAL, R. K. 1998. Inheritance of downy resistance in opium poppy: evidence of cytoplasmic control and paternal/biparental transmission. $J$. Med. Arom. Plant Sci., 20, 57-64.

DONOHUE, K. 1999. Seed dispersal as a maternally influenced character: mechanistic basis of maternal effects and selection on maternal characters in an annual plant. Am. Nat., 154, 674-689. 
GRIFFING, B. 1956. Concept of general and specific combining ability in relation to diallel cross. Aust. J. Biol. Sci., 9, 463-493.

IMBERT, E. 1999. The effects of achene dimorphism on the dispersal in time and in space in Crepis sancta (Asteraceae). Can. J. Bot., 77, 508-513.

IMBERT, E., ESCARRÉ J. AND LEPART. J. 1997. Seed heteromorphism in Crepis sancta (Asteraceae): performance of two morphs in different environments. Oikos, 79, 325-332.

IMBERT, E., ESCARRÉ J. AND LEPART. J. 1999. Differentiation among populations for life-history traits, morphology, head traits, and achene morph proportions in the heterocarpic species Crepis sancta (L.) Bornm. (Asteraceae). Int. J. Plant Sci., 160, 543-552.

IMBERT, E. AND RONCE, O. Phenotypic plasticity for dispersal ability in the seed heteromorphic Crepis sancta (Asteraceae). Oikos, in press.

KOFER, W., GLIMELIUS, K. AND BONNETT, H. T. 1991. Modifications of mitochondrial DNA cause changes in floral development in homeotic-like mutants of tobacco. Plant Cell, 3, 759-769.

LYNCH, M. AND WALSH, B. 1998. Genetics and Analysis of Quantitative Traits. Sinauer Associates, Sunderland, MA.

ogihARA, Y., FUTAMI, K., TSUJI, K. AND MURAI, K. 1997. Alloplasmic wheats with Aegilops crassa cytoplasm which express photoperiod-sensitive homeotic transformations of anthers, show alterations in mitochondrial DNA structure and transcription. Mol. Gen. Genet., 255, $45-53$.

OLIVIERI, I. AND GOUYON, P.-H. 1985. Seed dimorphism for dispersal: theory and implications. In: Haeck, J. and Woldentrop, J. W. (eds) Structure and Functioning of Plant Populations, pp. 77-90. North Holland, Amsterdam.

OlivieRI, I., MichalaKis, Y. AND GOUYON, P.-H. 1995. Metapopulation genetics and the evolution of dispersal. Am. Nat., 146, 202-228.

OUbORG, N. J., PIQUOT, Y. AND VAN GROENENDAEL, J. M. 1999. Population genetics, molecular markers and the study of dispersal in plants. J. Ecol., 87, 551-568.

PERONI, P. A. 1994. Seed size and dispersal potential of Acer rubrum (Aceraceae) samaras produced by populations in early and late successional environments. Am. J. Bot., 81, $1428-1434$.
POMPLitz, R. 1956. Die Heteromorphie der Früchte von Calendula arvensis unter besonderer Berücksichtigung der Stellungs- und Zahlenverhältnisse. Beitr. Biol. Pfl., 32, 331-369.

RUIZ DE ClAViJo, E. AND JIMENEZ, M. J. 1998. The influence of achene type and plant density on growth and biomass allocation in the heterocarpic annual Catananche lutea (Asteraceae). Int. J. Plant Sci., 159, 637-647.

SHAw, R. G. 1987. Maximum-likelihood approaches applied to quantitative genetics of natural populations. Evolution, 41, 812-826.

SHAW, R. G. AND PLATENKAMP, G. A. J. 1993. Quantitative genetics of response to competitors in Nemophila menziesii: a greenhouse study. Evolution, 47, 801-812.

SHAW, R. G. AND SHAW, F. H. 1994. QUERCUS: program for quantitative genetic analysis using maximum likelihood. Published electronically on the Internet, available via anonymous ftp from ecology.umn.edu/pub/quercus.

SOKAL, R. R. AND F. J. ROHLF. 1995. Biometry. Freeman, New York.

THIEDE, D. A. 1998. Maternal inheritance and its effect on adaptive evolution: a quantitative genetic analysis of maternal effects in a natural plant population. Evolution, 52, 998-1015.

VENABLE, D. L. 1985. The evolutionary ecology of seed heteromorphism. Am. Nat., 126, 577-595.

VENABLE, D. L. AND BURQUEZ, A. M. 1989. Quantitative genetics of size, shape, life-history and fruit characteristics of the seed-heteromorphic composite Heterosperma pinnatum. I-Variation within and among populations. Evolution, 43, 113-124.

VENABle, D. L., DYReson, E., PINERo, D. AND BeCERRA, J. X. 1998. Seed morphometrics and adaptive geographic differentiation. Evolution, 52, 344-354.

VLOT, E. C. AND BACHMANN, K. 1993. Genetics of the number of achenes and involucral bracts in interstrain hybrid D37 of Microseris douglasii (Asteraceae, Lactuceae). Biol. Zbl., 112, $7-17$.

ZENTGRAF, J., BACHMANN, K., CHAMBERS, K. L. AND PRICE, H. J. 1985. Modifiers of heterocarpy determine capitulum size in Microseris hybrid D 14 (Asteraceae, Lactuceae). Plant Syst. Evol., 151, 103-119. 